Magnus Ronn | LM Tucker | Ron Dulaney Jr. Sinclair, Mousazadeh, Safarzadeh | James Shraiky Marci Uihlein | Tang, Anderson, Aksamija, Hodge

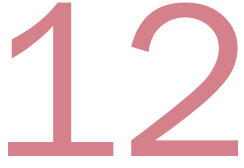

volume 9 | issue 1

\section{The low-income single-family house and the effectiveness of architects in affecting affordability}

Ron Dulaney Jr., West Virginia University

\section{Introduction: Architects aren't "getting to do the work"}

In 2005, Architectural Record published an article about post-hurricane rebuilding titled "Architects fight for a role in rebuilding after Katrina and Rita" (Sokol and Lubell 2005). The article explored architects' frustrations resulting from "the difference between offering to do the work and getting to do it" as well as a belief within the profession that architects were "being excluded from initial relief and planning efforts." In spite of early initiatives by organizations such the American Institute of Architects (AIA) and Architecture for Humanity, the broad architecture profession, as reflected in that article, viewed itself marginalized during initial rebuilding efforts focused on sheltering displaced residents. How could that be? While United States architects did long ago concede mass, single-family housing to others, by 2005 a movement within architecture to improve the quality of low-income affordable, single-family housing was growing. Inspired by the work of the late Sam Mockbee and the Auburn Rural Studio, numerous architecture schools were wading into the communityengaged residential 'design build' tradition initiated in the 1960s at Yale University (Hayes 2007). By Hurricane Katrina's 2005 landfall, it had been five years since Mockbee received a MacArthur Fellowship, and monographs had been published about the Rural Studio's work (Dean and Hursley 2002; Moos and Trechsel 2003). Design Corps (Bell 2004) and Architecture for Humanity (Sinclair and Stohr 2006) were rising stars of social activism within the profession. Several well-publicized affordable single family house design competitions, including the 2003 SECCA HOME House Project (David J. Brown 2004) and the 2004 Cradle to Cradle Home (Diana Brown 2005), had just taken place. In the midst of an increasing social activism and engagement with single family housing within its ranks, architecture nonetheless found itself in a "fight for a role in rebuilding."

The profession did, through ingenuity, persistence, and celebrity assistance, create high profile opportunities to contribute to post hurricane rebuilding. Marianne Cusato's Katrina Cottage, a proposed substitute for the FEMA trailers, was publicized through professional and popular presses alike (Bergeron 2006; Norris 2006). The "High Density on the High Ground" and "New Orleans Prototype House" competitions garnered 544 entries (Russell 2006), and the Biloxi Model Home project appeared in the New York Times (Arieff 2007) as well as national and international architectural publications (Howard 2008; 151: Porchdog 
House 2010). However, the publicity received by Brad Pitt's Make it Right in New Orleans dwarfed that received by these efforts. The Make it Right project appeared in popular publications including the New York Times, People, and 0: The Oprah Magazine as well as numerous publications associated with architecture and its allied disciplines. Allured, if not entranced, by these completed and ongoing efforts and the publicity associated with them, it would become easy to conclude that architects were earning a role not only in Gulf Coast rebuilding efforts but also in the broader conversation about how to meet the nation's demand for affordable low to mid income housing. U.S. architects, it appeared, were staking out a level of interest in mass, low-density, single-family housing perhaps unseen since the mid-twentieth century.

Still, architects were notably absent from the list of "local and national community development and design professionals" invited to speak at a 2009 affordable housing workshop hosted by West Virginia University (WVU). The workshop focused on single-family housing and was organized to "discuss trends, innovative approaches, best practices, and challenges in affordable and attainable housing." In light of the recent, high profile contributions of architects to housing along the Gulf Coast, how could architects be omitted, if not excluded, from such an event? Online publicity materials for similar university events across the country indicated the WVU event was not an isolated case. This suggested that the progress of architects to gain inclusion in addressing affordable low to moderate income single family housing needs along the post-hurricane Gulf Coast hadn't generalized to the national effort.

\section{'Housing Studies' and Architecture}

'Housing Studies' programs at United States universities, even at universities with architecture programs, are commonly situated within academic units such as Public Administration, Urban Planning, Finance, or Family and Consumer Sciences. These fields have distinctly different values than architecture (Figure 1). The WVU housing workshop was

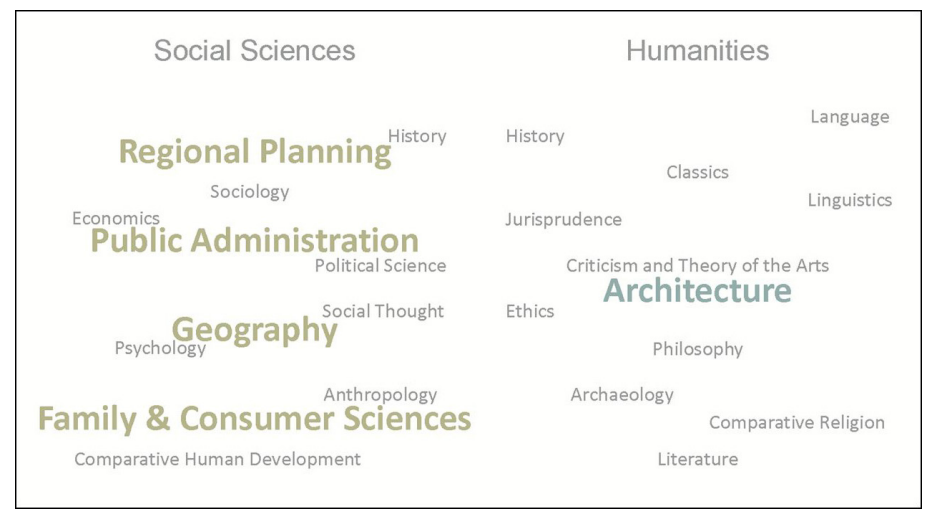

Figure 1: Disciplinary alignments of housing studies and architecture. Adapted from U. of Chicago Division of the Social Sciences and the National Endowment for the Humanities hosted by the Public Administration division. The basis of the workshop was that "creating opportunities for home ownership is one way this country can stabilize our economy." Architecture has traditionally situated itself within cultural fields while affordable housing has been approached in socio-economic terms. While policymakers and providers of housing may have failed to meaningfully engage culture, architecture has equally struggled, if not also failed, to successfully and consistently synthesize particular socio-economic parameters of low and moderate income housing. Frank Lloyd Wright's Usonian houses serve as a case in point.

Like Thomas Jefferson, for Wright home and land ownership exemplified the political culture of the republic. The house monumentalized the rise of the individual within a democratic republic. Wright conceptualized the Usonian house as a moderate-cost house typified by a "sense of spaciousness and vista we desire in order to liberate the people living in the house" (F. Wright 1938). To Wright the Usonian houses were intended to provide cultural and political edification in the face of the "the money interest" that had driven land speculation during the 1930s (Sergeant 1976). Wright publicized his Usonian house type to cost between $\$ 5,000$ and $\$ 6,000$, and the 1,345 SF Jacobs House (193637) did indeed cost $\$ 5,500$. However, subsequent Usonian houses cost more, sometimes exceeding $\$ 10,000$ (Sergeant 1976). The 1,540 SF Rosenbaum House (1939) cost $\$ 12,000$. While all of the Usonian houses were certainly modest compared to the $\$ 155,000$ spent at Fallingwater (1935), their construction costs far exceeded the national median house value of $\$ 2,940$ in 1940 (United States Census Bureau 2011). While acknowledging the many well-argued cultural, aesthetic, and technological achievements of these houses, it would be fair to call into question Wright's effectiveness at achieving a moderate-cost house type. Wright stated in 1938 that "the house of moderate cost is not only America's major architectural problem but the problem most difficult for her major architects" (Wright 1938). Depending on the source, the total number of Usonian houses designed and built ranges from 60 (PBS n.d.) to "hundreds" (McCarter 1997). Certainly their stylistic and organizational influence on the suburban house is remarkable given the relatively few number of houses that were realized. The number of houses provided by Wright's Usonian 'project' was modest compared to its contemporaries. The Jacobs House was constructed during the federal New Deal housing program, and the later Usonian houses paralleled the Levittown projects. Eleven thousand units were provided in approximately one-hundred New Deal communities (National New Deal Preservation Association n.d.) while in New York alone, Levitt and Sons built 17,447 houses (Levittown Historical Society n.d.).

The socio-economic parameters with which Wright struggled persist today. In a recent article on the Make it Right housing program, Catherine Slessor identified two areas where the project has been vulnerable to criticism. Stating what the author of this study also heard Make it Right director Tom Darden share at a 2010 ACSA Conference session, the 
square foot cost of the first fifty projects, while gradually declining, is expected to average approximately $\$ 150 /$ SF. The 2010 market rate in New Orleans was $\$ 125 /$ SF (Darden 2010). Slessor also wrote:

So far, with only 50 completed houses resettling 200 people, Make it Right seems like a well-meant but inadequate dent in a complex humanitarian crisis. But it only ever promised to deliver 150 houses. (Slessor 2011)

In Biloxi, a community that lost 3,500 houses from Hurricane Katrina (Arieff 2007), Architecture for Humanity's high-profile prototype program constructed seven homes from thirteen architects' proposals. James Russell (2008) reported that while innovative, "most [of the architects' proposals] cost too much to be built as designed" even with a partial reliance on volunteer labor. Russell also reported that the five singlefamily houses constructed by Global Green following its competition for a reconstruction project in New Orleans' Holy Cross neighborhood were "completed largely as designed, but only because fund-raising covered much higher than anticipated costs." Lower profile but no less noble efforts, such as those of Mississippi State University's Gulf Coast Community Design (GCCDS), have seemingly been more effective at achieving targeted costs in providing low-cost housing directly to individuals in need. However their efforts, as GCCDS Director David Perkes acknowledged, are "a small chip out of a huge obligation" (Russell 2008). David Sterling offered a critical extra-disciplinary viewpoint. While affirming the aspirations and efforts of architecture student activism, Sterling observed that their model of engagement "doesn't translate to a larger scale. Despite their sympathies, most architects don't make careers housing the poor because the housing industry can't make that pay" (2008). Collectively, these observations indicate that, even within architecturally significant and/or innovative works, architects have generally struggled to achieve the intended low to moderate cost targets and to develop design prototypes that compel broad adoption.

In this study clarification is sought about whether these observations about cost and impact are limited to conditions of post-hurricane rebuilding or indicative of a broader struggle observed by Frank Lloyd Wright nearly seventy five years ago. If architects cannot design houses that can be constructed at low to moderate cost and be broadly applicable to the nation's needs, then what is the basis of architects' relevancy to the socio-economic priorities of housing policymakers, administrators, planners, developers, and financiers? If there is a gap between architects' views and other housing disciplines' views of architects' relevancy to addressing affordable housing needs, what strategies might lead to a closing of that gap in order to make the architect's absence from discussions on the topic of affordable houses as notable to other housing disciplines as it is to architects?

\section{Affordable House Design Competitions}

Jack Nasar condensed Paul Spreiregen's stated benefits of the architecture design competition (1979) into discovering unrecognized talent, producing new solutions, and publicizing architecture (Nasar 1999). These benefits indicate the valued skills ("talent") and state-ofthe-art ("innovation") within architecture. Additionally they may measure agreement among architects and between architecture and the public ("publicity"). In this study, affordable house design competitions serve as cases for assessing the generalizability, beyond hurricane disaster responses, of critical observations about architects' effectiveness at addressing low to moderate cost single-family housing.

Selection criteria were established for the cases. Inclusion criteria included competitions to design a low to moderate cost single-family house prototype in the United States. In each selected competition, the stated cost targets were associated with a particular geographic location. The competitions selected were "open," and the design objectives were clearly and publicly stated. They were nationally publicized, increasing the probability of a large pool of submissions representing a broad range of practices within architecture. Each selected competition was juried. Each brief stated that jury selections would be constructed which provided expanded opportunities to measure the effectiveness of the selected designs in meeting design objectives. Selected competitions were administered within ten years preceding 2012 in order to situate the work temporally with Gulf Coast rebuilding efforts. Each competition selected did result in a constructed house. Competitions directly associated with post-disaster rebuilding, such as the "New Orleans Prototype House" competition and the "Sustainable Design Competition for New Orleans," were excluded. Three competitions met the selection criteria. They were the "SECCA HOME House Project: The Future of Affordable Housing" competition (2003), the "Cradle to Cradle (C2C) Home Competition" (2004), and the "99k House Competition" (2008). The SECCA and C2C competitions received tremendous attention from architects and designers with 442 and 625 design submissions respectively (Brown 2004; Law 2006). The 99k competition received 184 submissions (Rice Design Alliance 2008). The outcomes of each competition warranted book publication (Brown 2004; Rice Design Alliance 2008; MarshallBaker and Tucker 2011).

\section{SECCA HOME House Project}

The single-stage SECCA HOME House Project competition "challenged artists and architects to propose new designs for affordable and sustainable single-family housing for low-and moderate-income families" (Brown 2004). The SECCA brief called for proposals informed by a Habitat for Humanity prototype, utilizing sustainable materials, technologies, and methods, and delivered within a building construction budget of approximately $\$ 65,000$ for a 1,050 SF, three-bedroom, one bath house to $\$ 72,000$ for a $1,150 \mathrm{SF}$, four-bedroom, one-bath house in the Winston-Salem, NC area (Brown 2004). Michael Sorkin, Ben 
Nicholson, and Steve Badanes comprised the jury which recognized twenty five submissions with awards of merit.

Following the awards, SECCA competition advisor David Brown wrote of plans for SECCA to partner with the Housing Partnership of WinstonSalem/Forsyth County, Inc. and with Habitat for Humanity affiliate board member and private developer William Benton to build two sets of the awarded houses in SECCA's home city (Brown 2004). As of late 2011 no SECCA homes were built in Winston Salem. In a November 2011 newspaper article reporting on a neighborhood's desire to place a park on one set of vacant parcels purchased for the houses by Benton's corporation in 2005, Benton stated building had been delayed due to the "housing collapse." He still planned to build the houses but projected the cost per house to be between $\$ 250,000$ and $\$ 300,000$. The median house value in Winston Salem in early 2012 is $\$ 137,000$ (Smith 2012). Benton stated, "the trouble was that, I think, the designers were more interested in aggressive design than they were in low-income or lower cost" (Graff 2011). Cincinnati, Ohio received the first SECCA house in 2007. Two 1,400 SF houses based on S. Flavio Espinoza's award winning competition entry titled "Suburban Loft," modified by Espinoza and associate architect Alice Emmons, were built on donated land (Figure 2). The houses received LEED Silver certification. Each house cost $\$ 226,000$ to build, and city subsidies allowed each to be sold at a price of $\$ 180,000$ (Baverman 2007). In 2007 the median house price in the Cincinnati-Middletown metropolitan area was just over $\$ 156,400$ (U.S. Census Bureau 2007). In the "Suburban Loft" submission narrative,

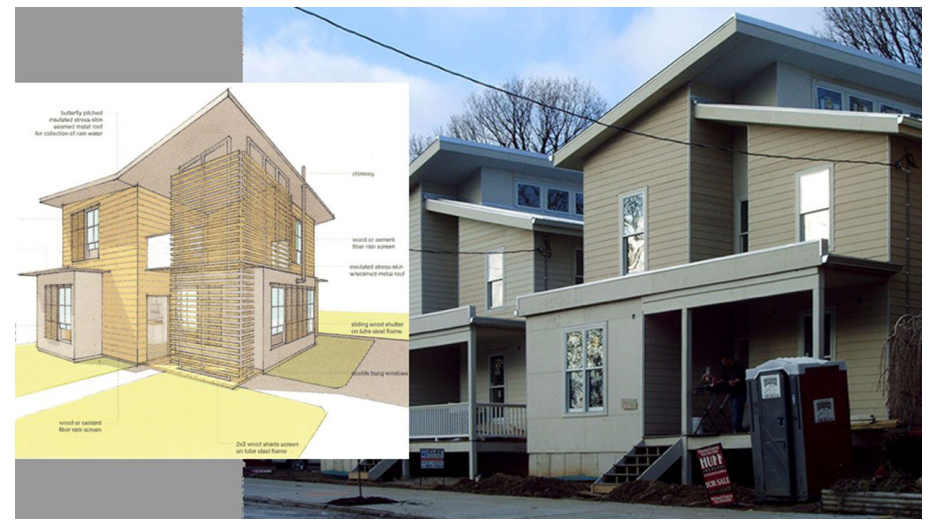

Figure 2: SECCA HOME/House winning entry as modified on right (Courtesy of Kevin LeMaster / Building Cincinnati) with S. Flavio Espinoza's original competition proposal inset on left (Courtesy of S. Flavio Espinoza / flavioespinoza.com)

low or moderate cost is framed as long-term energy costs, and the issue of initial construction cost is side stepped.

What is affordability? What this means to a low or moderate income family is that the initial affordability of a $\$ 70,000$ subsidized loan over 30 years is irrelevant if the energy costs of the house surpass the income growth of the household (Brown 2004, p 44).
The SECCA competition may well have identified unrecognized talent, produced new proposals, and publicized architecture. However, publicly accessible early indicators point to construction costs of realized projects that exceed not only the low cost criterion established by the competition organizers but also the median house values in Winston Salem and other locations. As significant as the cost variance, are the 'modifications' made to the original design in order, according to Emmons, "to suit the scope of the project" (Hayutin 2007). Visible exterior modifications included removing the prominent butterfly roof and lattice scrim. In the end, the constructed house lost its defining architecture elements and far exceeded the targeted initial cost.

\section{Cradle to Cradle House}

The single-stage Cradle to Cradle House competition charged entrants to "as specifically as possible, for one of the given sites [located in Roanoke, VA], design a home applying the ideology described in Cradle to Cradle: Remaking the Way We Make Things" (C2C Home n.d.). The program listed the issues as "creating a new 'machine'," "using resources effectively," "celebrating context," and "engaging industry." The given space requirements included three bedrooms and two baths. The program suggested a cost target of $\$ 100,000$, noting that " $75 \%$ of the homes in the City of Roanoke are valued below $\$ 100,000$." The jury was composed of Alexander Garvin, Daniel Libeskind/Yama Karim, William McDonough, Randall Stout, and Sarah Susanka.

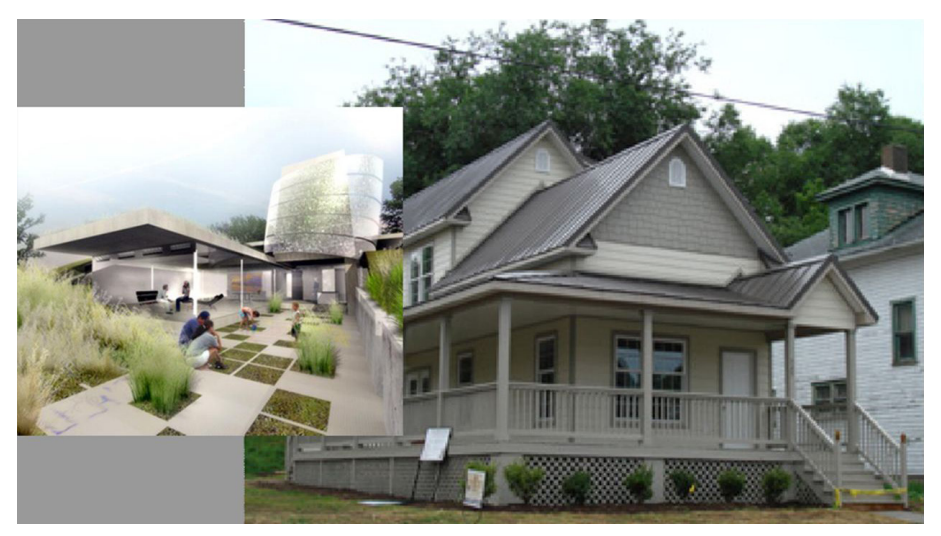

Figure 3: Constructed Cradle to Cradle entry submitted by Rife \& Wood on right (Courtesy of Rife \& Wood) with Coates Design's winning Cradle to Cradle Home competition proposal inset on left (Courtesy of Coates Design)

First through fourth places were awarded in both a professional category and a student category. While it would later make an "unbuilt" appearance in a "special Web-exclusive feature" of Architectural Record (2008), Matthew Coates and Tim Meldrum's first place proposal (Figure 3) was not built. In fact, one by one, the award winners from both categories were considered for construction and dismissed: 
One of the homes slated for construction was to be made of "rammed earth" . . . . Only it turns out that wouldn't be entirely practical in this climate, [competition organizer and architect, Greg] Lewis said. Another design slated to be built . . . was discovered to have a two-story glass front wall -- an aspect that was neither clear in the designs sent in, nor practical in a neighborhood (Chittum 2005).

Eventually, a non-awarded proposal by architects Steven Feather and Richard Rife (Figure 3) was built in 2007. The built 1,600 SF house was listed at $\$ 100,000$ (Adams 2007). Literature searches indicate the final construction cost has not been published. However, at the start of construction, the cost was estimated to be approximately $\$ 150,000$ excluding land acquisition costs, and the property was planned to be sold, with subsidies, for approximately $\$ 95,000$ (Law 2006). In 2007 the median value of owner-occupied housing in Roanoke was $\$ 155,500$ (U.S. Census Bureau 2007). In a local newspaper article about the finished project, Cradle to Cradle application was exemplified once. "The house's carpet is one example. It's made by Interface and includes an 800 number on the underside [for recycling upon removal]" (Adams 2007). Like the SECCA competition, publicly available information about the $\mathrm{C} 2 \mathrm{C}$ competition suggests that while it may generally exemplify the benefits of a competition summarized by Nasar, it also exemplifies that architects continue to struggle with integrating low cost affordability into architectural thought and practices.

\section{K House}

The double-stage 99k House competition administered by the Rice Design Alliance (RDA) and AIA Houston called for a single family house for the Gulf Coast region that could be initially built in Houston, TX. The brief limited floor area to 1,400 SF for 3 bedrooms and one and a half or two bathrooms. The successful competitor, the call stated, "will use sustainable building practices and materials with a special concern for affordability, longevity, energy savings benefits, and appropriateness of the hot, humid, Houston climate" (99k House Competition n.d.). The brief established a construction budget of $\$ 75,000$ on donated land and a sale price less than $\$ 99,000$ that would also cover financing, closing costs, commissions, overhead, and profit. Five jurors judged both stages of the competition. Michael Pyatok, Bryan Bell, David Lake, Rocio Romero, and Richard Farias comprised the jury. In the first stage, five finalists and seven honorable mentions were recognized, and a single winner was announced in the second stage.

The second stage of this competition distinguishes it from the previous two competitions. In the second stage each finalist received a modest stipend to develop construction drawings. Prior to final judging a professional building contractor conducted a quantity take-off and a construction cost estimate. The second stage preliminarily tested the constructability and probable cost of each final design proposal. The data resulting from this preliminary testing then informed the final selection of a design proposal. In the winning 1,200 SF, 3 bedroom, 2 bathroom proposal by Hybrid
I ORA (Figure 4), the second stage judging determined that certain technologies could not be afforded within the established construction budget. The built work did maintain some of the significant technologies initially proposed including an energy efficient geothermal heating and cooling system (KUHF 2009).

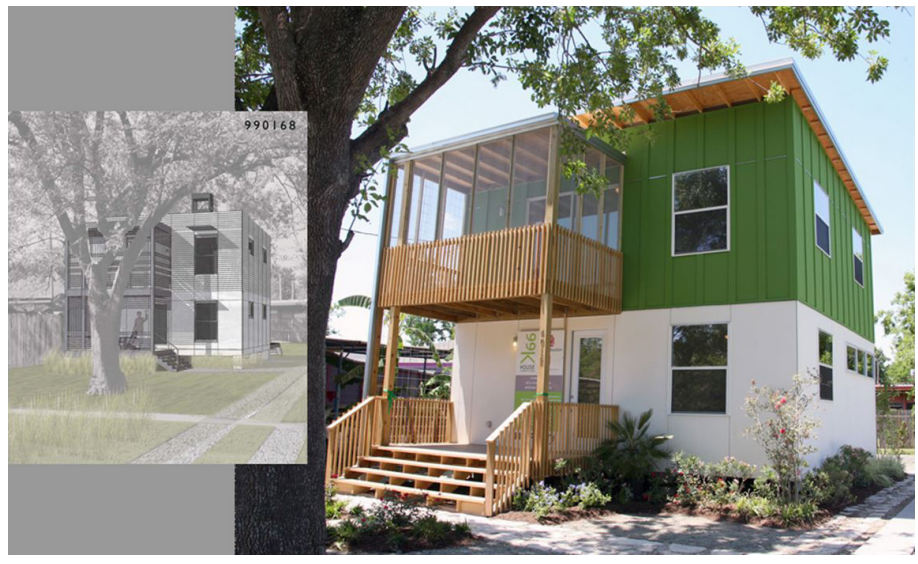

Figure 4: Hybrid/ORA's 99k House competition winning entry as-built on right and as proposed inset on left (Courtesy of ORA and Hybrid)

They designed the house on a four-foot module to reduce waste, with framing of exterior walls designed to link up at 24 inches, using fewer materials and fewer studs in the walls. Recycled and sustainable materials were also worked in. The house has cement board siding, pine flooring and recycled concrete paving.

There were some things they couldn't afford, like the green roof they wanted. Rainwater capture will irrigate the site but won't run through toilets or the laundry (Seattle Daily Journal of Commerce n.d.).

The final selection of a proposed design in the 99k competition included testing the validity of the expected cost claim associated with each entry. RDA Executive Director Linda Sylvan confirmed that the potential to complete the project for $\$ 99,000$ was the primary criterion for the selection of the winning entry. However, during the project, the cost limit was raised to $\$ 135,000$ (Sylvan, pers. comm.). Validation of estimated costs tethered the jury process to the likelihood that the awarded proposals could be built at low cost as the competition prescribed. Construction was completed during spring 2009. Because expenses were not tracked in detail, Sylvan was not able to pinpoint a final project cost (Sylvan, pers. comm.). Even at the increased $\$ 135,000$ budget, the project cost slightly below the Houston 2009 median house value of $\$ 139$, 800 (U.S. Census Bureau 2009). While material, constructional, and technical compromises are evident in the built project, formally the realized house varies little from the proposed design 


\section{Closing the Gap}

Truly low-cost single family houses are already achieved without architects through conventional, low-technology building methods and with the modest yet noble goal of providing basic shelter. Almost Heaven Habitat for Humanity in eastern West Virginia closely tracks construction costs and Executive Director Michelle Connor provided data to this study about recently completed projects based on house types it has developed over time (Connor, pers. comm.). Both houses had three bedrooms and one bathroom, and each was situated on $1 / 3$ acre within a small community developed by the affiliate. Technologies utilized in both houses included SIPS, in-slab radiant heat, and on-demand hot water systems. The project costs provided by Connor excluded the value of volunteer labor but did include site acquisition and community development costs (including roads, sanitary sewer system, and other utilities), and the purchase value of in-kind donations. Both projects were completed in 2008. A nearly 1,100 SF 'Ranch' type house cost $\$ 91,000$ and sold for $\$ 72,000$, and a 1,200 SF 'Heritage' model (Figure 5) cost $\$ 96,500$ and sold for $\$ 77,000$. The Almost Heaven affiliate is forty miles from Harrisonburg, VA, the closest location for which the Census Bureau provides housing data. In Harrisonburg, the median housing value in 2008 was $\$ 202,900$.

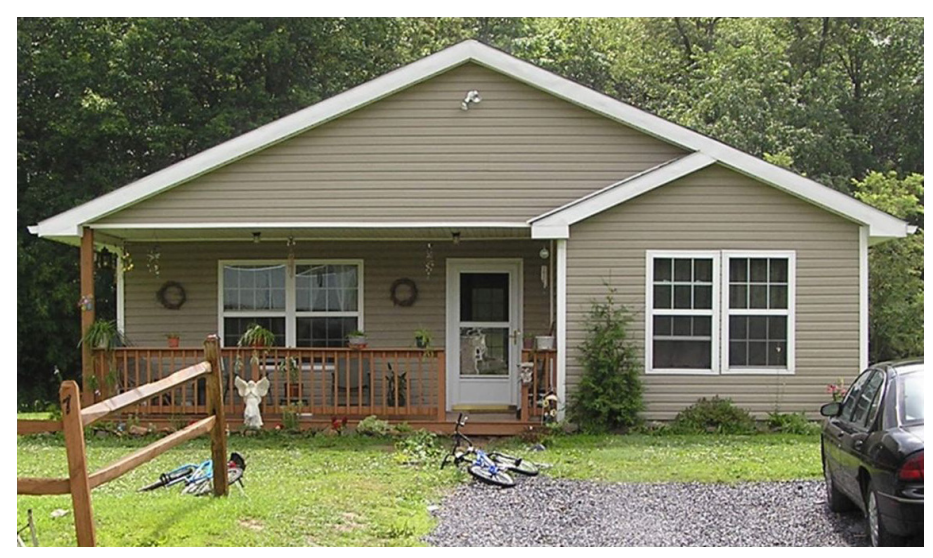

Figure 5: Heritage model house constructed by Almost Heaven Habitat for Humanity, Franklin, WV

If low-cost housing is already broadly accomplished without architects (albeit quantitatively still below the pressing demand), then how might architects better 'add value' without also 'adding cost'? How might the work of architects more broadly meet demand? Perhaps in effectively demonstrating answers to these questions architects might close the gap between "offering to do the work" and "getting to do the work" of addressing the pressing demand for low and moderate cost single family housing. As has been shown, in many of the highest profile, recent opportunities for architects to demonstrate an ability to improve the quality of low to moderate cost single family houses without adversely affecting financial affordability for targeted incomes, their abilities to accomplish both goals have been less than fully convincing. While the gap between architects "offering" and "getting to do" affordable, single family housing is what prompted the observations of high profile efforts by architects, this study is not intended to prove causal links. It does attempt to explore the relationship between architecture and other housing disciplines and architectures' recent high-profile efforts to meet the demand for low to moderate income, single family houses. It has explained how architects have performed using criteria of affordability and broad impact on demand. Finally, what can be learned through observations and explanations associated with these performances? How does architecture do better and perhaps become more relevant in 'doing good'?

While the competition format itself is worthy of closer examination in the three cases outlined, the study has demonstrated that the outcomes of recent house competitions reinforce observations related to architects effectiveness at providing housing in post-hurricane rebuilding. To paraphrase Wright, the low to moderate income house continues to be a major, difficult problem for the nation's architects. Low to moderate income affordability and facilitation of broad access to single-family works of architecture have been difficult to achieve. This study theorizes that three strategies may lead to greater effectiveness in addressing these difficulties and focuses on the second two. The first strategy is revealed by the competition organization itself. The $99 \mathrm{k}$ competition was achieved at the lowest actual cost to construct, and a house below the median house value for its location was realized. The lessons of the second stage in this competition include the benefits of collaboration across disciplines during project planning and design. Participation in the process by allied disciplines (e.g. a building contractor) and low-cost housing providers (e.g. juror Richard Farias represented the Houston Tejano Center) informed design and construction decisions necessary for achieving a low or moderate cost house, depending on whether the house cost closer to $\$ 99 \mathrm{k}$ or $\$ 135 \mathrm{k}$. It also appears that an attitude of interdisciplinary appreciation, if not also collaboration, prevailed to the end as indicated by $99 \mathrm{~K}$ house building contractor David Harvey. He stated "I like the design itself. I think it's kind of a unique design because there is the flexibility of changing the rooms around, and even changing some of the built-in furniture, a pretty good effort from the design side, and we just did our best to try to follow it" (KUHF 2009).

The second strategy is to really understand and target affordability and to direct efforts toward local and regional needs. The third strategy is to approach the design of low and moderate cost housing with a research rigor parallel to the scientific method in the natural and social sciences.

\section{Defining and Targeting Affordability}

Affordability is the most restrictive parameter in the design of affordable, owner-occupied housing. The U.S. Department of Housing and Urban Development's (HUD) definition of affordability is for a household 
to pay no more than $30 \%$ of its annual income on housing. When targeting affordability then, the immediate question is for whom will a house be affordable? HUD categorizes a household income based on its relationship to the Average Median Income of the geographic area in which the household exists (U.S. Department of Housing and Urban Development 2011) (Figure 6). In metropolitan areas, an AMI is established for the entire Metropolitan Statistical Area (MSA) whereas in non-metropolitan areas the AMI is established for each county. A factor for the number of persons living in a household is applied to the AMI to adjust income limits for each category. The default limit is based on a four person household. The AMI is based upon Census Bureau data and updated annually.

\begin{tabular}{|l|c|}
\hline Income category: & $\begin{array}{c}\text { Household income must not } \\
\text { exceed: }\end{array}$ \\
\hline Moderate Income & $120 \% \mathrm{AMI}$ \\
\hline Low Income & $80 \% \mathrm{AMI}$ \\
\hline Very Low Income & $50 \% \mathrm{AMI}$ \\
\hline Extremely Low Income & $30 \% \mathrm{AMI}$ \\
\hline
\end{tabular}

Figure 6: Household Income Limits per Income Category as a Percentage of Area Median Income (AMI); Adapted from HUD

To exemplify what this means, the affordable housing cost limit in each income category for a four person household has been calculated based on 2009 statistics for counties or Metropolitan Statistical Areas (MSA) with the highest and lowest median incomes in West Virginia (Figure 7). While state and national median incomes are not used by HUD, they are provided in the figure to demonstrate the range of housing cost limits i.e. affordability. Based on the West Virginia AMI, monthly housing cost limits for very low to moderate income range dramatically, depending on geographic location, from $\$ 375$ to $\$ 1,450$. This translates to a house sale price range of approximately $\$ 34,000$ to approximately $\$ 180,000$ for a four person household. This suggests that owner-occupied 'low to moderate affordable housing' may be too broad in describing individual projects and research agendas.
According to the last five year West Virginia Proposed HUD Consolidated Development Plan, "there is a significant need for decent, affordable, owner-occupied housing" in the state. According to the proposed plan, "no owner-occupied housing units in West Virginia would be affordable to households with incomes below 30\% MFI." It should be noted that the area in West Virginia with the highest AMI is associated with Washington, $\mathrm{DC}$, and this AMI nearly doubles the next highest one. The second major conclusion of the report is that severe rental affordability also exists for these extremely low income families. According to the 2000 HUD State of the Cities Database (SOCD) Comprehensive Housing Affordability Strategy (CHAS) Data there were nearly 52,000 extremely low income West Virginia families in rental housing. West Virginia's strategic response to these two major conclusions is to prioritize assistance to eligible and qualified public housing (and HUD Section 8 voucher) tenants to become first-time homeowners of single family detached houses. This in turn makes subsidized public housing units available to lower income families. The plan also references a 1998 state report of 83,000 'frustrated' renters - renters who are demographically inclined toward homeownership "but who may be discouraged from doing so due to existing homeownership data." The state views the transition of these 'frustrated' renters to homeowners as opportunities to make more affordable rental housing available to lower income renters.

Clearer focus by architects on those affordable housing needs identified through multi-disciplinary collaborative efforts such as HUD Development Plans would provide opportunities to bring our efforts into alignment with broader housing initiatives. For example in West Virginia architects might focus on improving the quality and attainability of moderate income owner-occupied housing in order to move the state's 'frustrated' renters into homeownership; Or on improving the quality and attainability of low income owner-occupied housing to move eligible and qualified public housing tenants into homeownership. Both of these efforts improve opportunities not only for the new home-owner, but for providing better rental opportunities for very low and extremely low income families for whom homeownership is not yet feasible. Such focused, supportive efforts might further earn architects a position of relevance among

\begin{tabular}{|c|c|c|c|c|c|}
\hline \multirow[b]{2}{*}{ Area } & \multirow{2}{*}{$\begin{array}{c}2009-2010 \text { HUD } \\
\text { Area Median Income }\end{array}$} & \multicolumn{4}{|c|}{ Annual Affordable Housing Cost Limits for each Income Category } \\
\hline & & Moderate & Low & Very Low & Extremely Low \\
\hline$<<$ County $>>-$ low & $\$ 43,100$ & $\$ 15,516$ & $\$ 10,344$ & $\$ 6,465$ & $\$ 3,879$ \\
\hline <<Metro Statistics Area >> - high & $\$ 102,700$ & $\$ 36,972$ & $\$ 24,648$ & $\$ 15,405$ & $\$ 9,243$ \\
\hline <<State $>>$ (for comparison) & $\$ 48,400$ & $\$ 17,424$ & $\$ 11,616$ & $\$ 7,260$ & $\$ 4,356$ \\
\hline U.S. (for comparison) & $\$ 64,000$ & $\$ 23,040$ & $\$ 15,360$ & $\$ 9,600$ & $\$ 5,760$ \\
\hline
\end{tabular}

Figure 7: Example of Variation in Annual Affordable Housing Cost Limit per Income Category, 2009-2010 HUD AMI, West Virginia; Adapted from HUD 
housing professionals on the matter of providing owner-occupied affordable housing. Ultimately, however, architects must demonstrate that their efforts are effective. This requires not only a summary of achievements, but also the data and methodologies that contributed to them, and 'failures' as well as successes encountered during the work.

\section{Design and Research}

Architectural design is the synthesis of multiple design parameters which widely vary from project to project. Thus, design as an activity typically results in a particular, individual product or building. The success of the design of a building may only be fully assessed after construction. In a recent article on architectural research, Stephen Kieran critically observes that "architecture exists in a world where all we ever do is design and build prototypes, with little real reflection and informed improvement from one act of design to the next (Kieran 2007). Critically questioning this condition has recently led to a probing within the discipline about how design may constitute research. How do the design activities of the architect generate new knowledge or understanding and thus constitute a valid mode of research? Generally, a primary way architects gain knowledge and understanding of their subject "is through the act of designing itself, and through the experience and interpretation of other designs" (Lawson 2002). To understand design research, it may be helpful to compare scientific and design methodologies for generating new knowledge or integrating existing knowledge in a new synthesis. An architectural design proposal may be equated to a scientific hypothesis, and the subsequent construction (and post-occupancy evaluations) of the design may be equated to experimental studies in the sciences. However, it "might be thought that the significant difference between the processes of scientific research and design research lies in the repeatability of experiments, and in the full disclosure of data and methodology. Architects, and indeed other designers, do not habitually share such details ..." (Weinstock 2008). Architects have traditionally neglected to disclose data and methodologies related to their designs and the subsequent constructions. The result is that design research has remained in the realm of developing personal or proprietary knowledge rather than generating disciplinary knowledge.

In addition to appearing good and fitting well, buildings are increasingly expected to perform and be performed well. Performance as a goal and measure of building suggests the need to inform architectural design with data or evidence. Such data-informed or evidence-based design is expanding beyond the healthcare industry where it was introduced around 2003. In an early description of an 'evidence-based designer', healthcare architect Kirk Hamilton states that "evidence-based healthcare designers make critical decisions, together with informed clients, on the basis of the best available information from credible research and the evaluation of completed projects" (Hamilton 2004). The need for credible research suggests the need to bring personal and proprietary knowledge generated through design and evaluation of built projects into the realm of disciplinary knowledge. Knowledge becomes disciplinary through the disclosure of methodologies and the collection, organization and dissemination of data. Repeatability in design research is more difficult to achieve because "each design is an answer to a set of questions and circumstances that are unique" (Weinstock 2008). It is unlikely that any set of variables related to one project would be repeated exactly in another project. Therefore, neither the need nor the opportunity exists to repeat a synthetic design 'hypothesis' related to a particular set of variables. Architectural design typically results in a 'one off' product. This has traditionally discouraged the development of disciplinary data bases (beyond cost data). Consequently there has been little need or desire for the disclosure of design methodologies.

Within a synthetic design process, individual parameters and variables are interdependent. While they may be isolated for the purpose of observation and interpretation, they may not be manipulated in isolation. Michael Weinstock states that "architectural research is possible, but tends to proceed by incremental advances, and longer term research goals have to be conducted through a series of realized experiments" (Weinstock 2008). Architectural design research requires data collected from realized projects which equate to the experimental studies of the sciences. In the 1960s Post-Occupancy Evaluation (POE) emerged within architectural practice to diagnose building performance. POE methodologies have more recently been championed and further developed by Wolfgang Preiser (1995, 2001). However, when conducted, POEs are 'additional services' of the architect, and the cost of these services has limited them to commercial projects and for repetitious building programs. Even within this relatively narrow group of applications, the impact of POEs in expanding disciplinary knowledge has been inconsequential due to the lack of dissemination of such studies. The dissemination of data and its analysis will, as Hamilton has suggested, permit the act of drawing "rationale inferences" from data during subsequent design processes. Even very general dissemination such as the technologies integrated into the constructed $99 \mathrm{k}$ house is a beginning for building disciplinary understanding and advancing architects' contributions to meeting low and moderate income housing demands.

\section{Conclusion}

In the United States, 46.2 million people, including 16.4 million children, live below the poverty line (DeNavas-Walt, Proctor, and Smith 2011). These people, along with many others living on income between poverty and moderate levels, are particularly subject to unaffordable and/or inadequate housing. The capacity of architects to address broad societal conditions such as the demand for affordable housing is limited if they address those conditions solely within a cultural field and through the design of 'one-off' products. In an article commenting on the role of architects in addressing housing problems, Thomas Fisher states that just as medicine has evolved a public health model focused on addressing the needs of groups of people (in addition to the traditional, individual 
doctor/patient relationship), so should architecture evolve, in addition to the architect/client model, "a public-health version of our profession" (Fisher, 2006). He calls for architects to address housing issues with architectural implications through developing "accredited programs to prepare students for such work, funded research to develop new forms of housing and infrastructure, and committed practitioners ready to work in the nonprofit, corporate, and governmental sectors focused on shelter and habitat." He goes on to say that architects have much to offer in addressing such crises, "but we cannot address them one family at a time."

In this paper, recent case studies have been utilized to explore the gap between the potential value of the architecture profession in achieving low to moderate income, affordable, owner occupied housing and the profession's apparent effectiveness at doing so. In addition to recent cases, study of more distant historical precedents may further inform potential strategies for closing this gap. Perhaps Fischer's proposal of shifting away from a "one-off" design paradigm, evident in the outcomes of the competition case studies explored in this paper, warrants further assessment of the short-lived Architects' Small House Service Bureau. This bureau was established to expand the profession's impact on the design of small, moderately priced single-family housing during the 1920s (G. Wright, 1981).

Maybe the benefits of interdisciplinary engagement and collaboration evident in the 99k House competition warrants greater study of historical collaborative relationships such as the one between developer Joseph Eichler and architects Anshen + Allen (and others) that resulted in the realization of a large number of moderately-priced post-World War II homes in California. In a brief essay on Ernest Braun's early photos of Eichler homes, Gwendolyn Wright observes that the photographs "announce a distinctively American hybrid functionalism" fusing "structure and economy" with "comfort, familiarity, and joy." These photos, she concludes, "reveal a contemporary concept of collaboration: between architect and builder, building and setting (both natural and social), director and actors" which is born out of a kind of "experimentation" (G. Wright, 2001).

Finally, if the design and development of achievable, affordable, low and moderate cost housing is undertaken today as a kind of experimentation, affordability goals must be clearly articulated and decisions informed by data (or 'evidence') associated with project-related variables. This data, collected from previously realized projects and made accessible for future projects, supports the drawing of "rational inferences" during the design process (Hamilton, 2004). As a discipline, architecture must develop a disciplinary body of evidence that makes its potential contribution to meeting affordable housing needs irrefutable by professionals in other disciplines.
While housing is a condition addressed by many disciplines, the architect's approach is synthetic. It engages the critical questions of our culture and discipline while facilitating livability, sustainability, and affordability. U.S. architects have set among their collective sights the design and construction of good, affordable, single-family housing for citizens of all income levels. However, to more effectively realize this vision, architects must close the gap between "offering to do" such work and "getting to do" it. Architects must expand their impact beyond the single project, engage collaboratively with those fields that currently have the detached housing markets "captured," and further develop and disseminate evidence of architects' effectiveness at improving the qualities of affordable housing while maintaining its affordability. With a recent, collective, body of work to examine and to inform future work, and a strong emerging interest in design research, it appears that the profession of architecture is wellpositioned to close that gap.

\section{Endnotes:}

1. e.g. Usonian houses, California case study houses, etc.

2. One notable exception is the Harvard Joint Center for Housing

Studies which is jointly affiliated with the jointly affiliated with the

Graduate School of Design and the Harvard Kennedy School.

3. Paul Spreiregen was the Professional Advisor to the Vietnam Veteran's Memorial Competition.

4. For home ownership, mortgage, taxes, insurance, and utilities combined should not exceed $30 \%$ of household income.

5. Also referred to as Median Family Income (MFI)

6. The HUD adjustments to AMI for household size are as follows: The HUD adjustments to AMl for household size are as follows: Number of Persons in Family and Percent Adjustment to AMI 7. Assuming a down payment of $3.5 \%$, a monthly escrow payment in the range of $\$ 100-300 /$ month , a mortgage loan interest rate of $7 \%$ paid over 30 years, and $\$ 50-150$ per month in utilities, this translates to monthly mortgage payment of approximately $\$ 225$ to $\$ 1200$

Bibliography:

"151: Porchdog House." 2010. Architectural Review 228: 70-71.

Rice Design Alliance \& American Institute of Architects, Houston Chapter. 2008. 99k House Competition. Houston: RDA/AIA, Houston.

99K House Competition. n.d. Retrieved Mar 18, 2012 from http:/l the99khouse.com

"99K House Competition: Rice Design Alliance and AIA Houston Announce Finalists," 2008. Cite: A Publication of the Rice Design Alliance 74: 6-8.

Adams, Matt. 2007. "Roanoke's first C2C house is unveiled." Ronaoke Times, September 07.

Ahrentzen, Sherry. 2008. "Fleshing out green." Newsletter of the Committee on the Environment (COTE), American Institute of Architects: Spring 2007. 31 Dec 2008 http://info.aia.org/nwsltr_cote. cfm?pagename=cote_a_0703_fleshing 
Architectural Record. 2008. "Unbuilt Houses 2008." Accessed 03.18.2012. http://archrecord.construction.com/residential/unbuilt/ archives/2008/08_c2c/default.asp

Arieff, Allison. 2007. "Design Steps Up in Disaster's Wake." New York Times: August 02.

Baverman, Laura. 2007. "Green Building Movement Finds a Home in Northside." Business Courier of Cincinnati, October 19. Accessed March 18, 2012. http://www.bizjournals.com/cincinnati/stories/2007/10/22/ story $15 . \mathrm{html}$.

Bell, Bryan, ed. 2004. Good Deeds, Good Design: Community Service through Architecture. NY: Princeton Architectural Press.

Bergeron, Angelle. 2006. "Designers hope Katrina Cottages will replace FEMA trailers." Architectural Record 194, no. 4: 36.

Brown, David J., ed. 2004. The HOMEHouse Project: The Future of Affordable Housing. Cambridge, MA: The MIT Press.

Brown, Diana. 2005. "C2C winners announced." Environmental Design + Construction Mar: 42-45.

Chittum, Matt. 2005. "1st C2C house nears construction: Building an environmentally friendly house has been an experiment in frustration." Roanoke Times, November 18.

Christie, Les. 2007. "Home prices drop for fourth straight quarter." CNN Money, August 15. Accessed March 18, 2012. http://money.cnn. com/2007/08/15/real_estate/NAR_home_prices_lower/index.htm

C2C Home. n.d. "Design Assignment." n.d. Accessed Mzrch 18, 2012. http://web.archive.org/web/20060210231345/http://c2c-home.org/ design.htm

Darden, Tom. 2010. Comments made during special focus session titled "Make it Right" during the annual meeting of the Association of Collegiate Schools of Architecture (ACSA), New Orleans, Louisiana, March 6.

Dean, Andrea Oppenheimer and Timothy Hursley. 2002. Rural Studio: Samuel Mockbee and the Architecture of Decency NY: Princeton Architectural Press.

DeNavas-Walt, Carmen, Bernadette D. Proctor, and Jessica C. Smith. 2011. "Income, Poverty, and Health Insurance Coverage in the United States: 2010." United States Census Bureau. Accessed March 18, 2012. http://www.census.gov/prod/2011pubs/p60-239.pdf

Ehrlich, Brent. 2007. "Cradle to Cradle: The Completely Recyclable Home." Green Builder $p 10$

Fisher, Thomas. 2006. "The Profession Must Harness its Talents to Address Housing Problems of an Unprecedented Scale," Architecture 95 Issue 2: 72.

Flade, Antje. 2007. "No Place Like Home," Scientific American Mind Vol. 18 Issue 1: 70-75.

Graff, Laura. 2011. "Neighbors call for park in long-vacant lot." Winston Salem Journal, November 5. Accessed March 18, 2012. http://www2. journalnow.com/news/2011/nov/05/wsmain01-neighbors-call-for-parkin-long-vacant-lo-ar-1576461

Hamilton, Kirk. 2004. "The New Evidence-Based Designers," Interiors \& Sources January: 58-59
Hayes, Richard W. 2007. The Yale Building Project: The First 40 Years. New Haven, CT: Yale University Press.

Howard, Sebastian. 2008. "The Coastguard." Architectural Record 196, no. 10: 106.

Hyutin, Marnie. 2007. "Life imitates art." Cincinnati Magazine April: 154155.

Kieran, Stephen. 2007. "Research in Design: Planning Doing Monitoring Learning." Journal of Architectural Education Vol. 61 Issue 1: 27-31.

KUHF: Houston Public Radio. 2009. "The 99k house looks more expensive." Accessed 03.10.2012. http://app1.kuhf.org/ articles/1245192040-The-99K-House-Looks-More-Expensive.html

Law, Violet. 2006. "First Cradle to Cradle House Built in Roanoke," Architectural Record News, Accessed March 13, 2012. http://archrecord. construction.com/news/daily/archives/060713cradle.asp

Lawson, Bryan. 2002 "The Subject that Won't Go Away ... but Perhaps We Are Ahead of the Game: Design as Research." arq: Architectural Research Quarterly Vol 6 No 2: 109-114.

Levittown Historical Society. n.d. "A Brief History of Levittown, New York." Accessed Mar 14, 2012. http://www.levittownhistoricalsociety.org/history. $\mathrm{htm}$

Lind, Carla. 1994. Frank Lloyd Wright's Usonian Houses (Rohnerte Park, CA: Pomegranate Art Books)

Marshall-Baker, Anna and Lisa Tucker. 2011. Cradle to Cradle Home Design: Process and Experience. New York: Fairchild Books.

McCarter, Robert. 1997. Frank Lloyd Wright: London: Phaidon Press.

McDonough, William \& Michael Braungart, 2002. Cradle to Cradle: Remaking the Way We Make Things (NY: North Point Press)

Moos, David and Gail Trechsel, eds. 2003. Samuel Mockbee and the Rural Studio: Community Architecture. NY: Distributed Art Publishers.

Nasar. Jack. 1999. Design by Competition. Cambridge: Cambridge University Press.

National New Deal Preservation Association. n.d. "Appendix: Complete List of New Deal Communities." Accessed March 14, 2012. http://www. newdeallegacy.org/table_communities.html

Norris, Michelle. 2006. "Law Stands in the Way of Sturdy Katrina Cottages." All Things Considered (NPR) Mar 20: EBSCOhost (accessed March 10, 2012).

Preiser, Wolfgang F.E.. 1995. "Post-Occupancy Evaluation: How to Make Buildings Work Better," Facilities Vol. 13 Issue 11: 19-28.

Preiser, Wolfgang F.E.. 2001 "Feedback, Feedforward and Control: PostOccupancy Evaluation to the Rescue." Building Research \& Information Vol. 29 Issue 6: 456-459.

PBS. n.d. "Usonian House: The Life and Work of Frank Lloyd Wright". Accessed March 14, 2012. http://www.pbs.org/flw/buildings/usonia/ usonia_wright.html

Russell, James S. 2006. "Building a Better Gulf South." Architectural Record 194, no. 6: 112.

Russell, James S. 2008. "Biloxi Clues." Architectural Record 196, no. 10: 100-105. 
Seattle Daily Journal of Commerce. n.d. Accessed 03.14.2012. "http:// www.djc.com/blogs/SeattleScape/2008/04/28/green-design-on-a-dimein-seattle

Sergeant, John. 1976. Frank Lloyd Wright's Usonian Houses: The Case for Organic Architecture. NY: Whitney Library of Design.

Sinclair, Cameron and Kate Stohr, eds. 2006. Design Like You Give a Damn: Architectural Responses to Humanitarian Crises. NY: Metropolis Books.

Slessor, Catherine. "The Mississippi floods give new urgency to the AIA's housing debate." Architectural Review 229, no. 1372: 30.

Smith, Nancy F. 2012. "Ten Best Places to Retire." CBS Money Watch Feb 22. Accessed 03.12.2012. http://www.cbsnews.com/8334-505146_16257382790/the-10-best-places-to-retire

Sokol, David, and Sam Lubell. 2005. "Architects fight for a role in rebuilding after Katrina and Rita." Architectural Record 193, no. 11: 29. Spreiregen, P.D. 1979. Design competitions. New York: McGraw-Hill. State of West Virginia, Executive Summary, Proposed HUD Consolidated Development Plan 2005-2009: Feb 28, 2005. Retrieved May 02, 2009 http://www.wvdo.org/community/Executive Summary.pdf

Sterling, Bruce. 2008. "Do-Bad Architecture." Architectural Record 196, no. 10: 86.

United States Department of Housing and Urban Development, Fiscal Year Income Limits Documentation System. Retrieved Sep 26, 2009, from http://www.huduser.org/datasets/il/il2009/select_Geography.odb United States Department of Housing and Urban Development, State of the Cities Data Systems: Comprehensive Housing Affordability Strategy (CHAS) Data. Retrieved May 06, 2009, from http://socds.huduser.org/ chas/index.htm

United States Census Bureau. 2007. Median Housing Value of OwnerOccupied Housing Units (Dollars) - United States -- Metropolitan and Micropolitan Statistical Area; and for Puerto Rico. Accessed March 14, 2012. http://factfinder2.census.gov/faces/tableservices/ jsf/pages/productview.xhtml?pid=ACS_07_1YR_GCT2510. US22PR\&prodType=table

United States Census Bureau. 2009. Median Housing Value of OwnerOccupied Housing Units (Dollars) - United States -- Metropolitan and Micropolitan Statistical Area; and for Puerto Rico. Accessed March 14, 2012. http:/ffactfinder2.census.gov/faces/tableservices/ jsf/pages/productview.xhtml?pid=ACS_09_1YR_GCT2510. US22PR\&prodType=table

United States Census Bureau. 2011. Historical Census of Housing Tables: Home Values. Accessed Mar 14, 2012. http://www.census.gov/ hhes/www/housing/census/historic/values.html

United States Department of Housing and Urban Development. 2011. "FY 2011 HUD income limits briefing material." Accessed March 14, 2012. http://www.huduser.org/portal/datasets/il/il11/ IncomeLimitsBriefingMaterial_FY11_v3.pdf

Weinstock, Michael. 2008. "Can Architectural Design Be Research?" Architectural Design Vol. 78 Issue 3: 112-115.
West Virginia University. 2009. "WVU hosts affordable housing workshop." Accessed Mar 19, 2012. http://eberly.wvu.edu/eberly_news/2009/4/13/ wvu-hosts-affordable-housing-workshop

Wright, Frank Lloyd. 1938. "Frank Lloyd Wright, Architect: House for \$5,000-6,000 Income." Architectural Forum Vol. 68.

Wright, Gwendolyn. 1981. Building the Dream: A Social History of Housing in America. Cambridge, MA: The MIT Press.

Wright, Gwendolyn. 2001. "Performance Standards." Places Vol. 14 Issue 2 